\title{
A case control study of role of lipid profile in polycystic ovarian syndrome: is there any role in non-obese polycystic ovary syndrome?
}

\author{
Soumya Ranjan Panda ${ }^{1}$, Prashant Kumar Rout ${ }^{2}$, Charu Chandra ${ }^{1}$
}

\footnotetext{
${ }^{1}$ Department of Obstetrics and Gynecology, AIIMS, Jodhpur, Rajasthan, India

${ }^{2}$ Department of Obstetrics and Gynecology, Veer Surendra Sai Institute of Medical Sciences and Research, Burla, Odisha, India
}

Received: 18 April 2016

Accepted: 13 May 2016

\section{*Correspondence:}

Dr. Soumya Ranjan Panda,

E-mail: drsome4141@gmail.com

Copyright: ( $)$ the author(s), publisher and licensee Medip Academy. This is an open-access article distributed under the terms of the Creative Commons Attribution Non-Commercial License, which permits unrestricted non-commercial use, distribution, and reproduction in any medium, provided the original work is properly cited.

\section{ABSTRACT}

Background: Polycystic ovary syndrome (PCOS) is characterized by hyperinsulinemia, impaired glucose tolerance, obesity, hyperandrogenism and abnormal lipid profile. Most of the studies involving lipid profile in PCOS are confounded by the factor of obesity. Here in our study we have tried to compare lipid profile in PCOS cases and healthy controls excluding obesity as a confounding factor.

Methods: This is a case control study done between January 2013 to january2014 in VSS MCH, Burla, Odisha, India. The cases $(n=50)$ diagnosed as PCOS based on Rotterdam's criteria and 50 controls of equivalent age group and body mass index without any endocrinopathy and not on hormonal therapy were selected. Lipid profile was compared for both the groups.

Results: The Mean level of total cholesterol in the study and control group is $202.12 \pm 40.18 \mathrm{mg} / \mathrm{dl}$ and $171.48 \pm 17.74$ $\mathrm{mg} / \mathrm{dl}$ respectively and this is statistically highly significant ( $\mathrm{p}$ value $<0.0001$ ). Similarly the mean of triglyceride level in cases and controls is $162.38 \pm 70.40 \mathrm{mg} / \mathrm{dl}$ and $131.46 \pm 27.16 \mathrm{mg} / \mathrm{dl}$ respectively which is also statistically significant ( $\mathrm{p}$ - value $=0.0046$ ). In contrast to the above finding the change in mean level of HDL, LDL and VLDL is statistically not significant. So it's found that the atherogenic lipid profile found in PCOS patients is independent of their age and body mass index.

Conclusions: So we recommend that both lean as well as obese PCOS patients should be screened for lipid profile to prevent cardiac complications.

Keywords: PCOS, Lipid profile, triglyceride, cholesterol, HDL, LDL, VLDL

\section{INTRODUCTION}

Polycystic ovarian syndrome (PCOS) is one of the most common endocrine disorders in women of reproductive age and the prevalence being $6-10 \%$ of women worldwide based on the National Institute of Health criteria and as high as $15 \%$ when the broader Rotterdam criteria are applied. ${ }^{1}$ In addition to abnormal morphology of the ovary, increased ovarian production of androgens and hyperinsulinemia is present in about $80 \%$ of obese women with PCOS and $50-70 \%$ of all women with PCOS. ${ }^{2-5}$ Insulin resistance is thought to be the central pathogenic factor for associations between PCOS and metabolic syndrome or syndrome ' $\mathrm{X}$ which comprises of hypertension, glucose intolerance, obesity, lipid abnormalities and coronary artery disease. ${ }^{6,7}$ So it seems not surprising that measuring lipid profile in PCOS patients is helpful for prediction of lipid abnormalities. But the challenge remains in the fact that most of the studies comparing lipid parameters in PCOS patients are biased by obesity which is frequently associated with PCOS. Occurrence of lipid abnormalities and its pathogenesis in PCOS especially in the lean sub group has remained controversial and need to be studied more. 
Based on the importance of lipid abnormalities and its association with cardiovascular disease in PCOS women, the aim of this study is to compare the serum level of various lipid parameters in women with and without polycystic ovarian syndrome (PCOS) independent of their age and body mass index (BMI).

\section{METHODS}

This study was conducted at Veer Surendra Sai Institute of Medical Sciences and Research, Burla, Odisha, India during January 2013 and January 2014. The type of the study is Case-control study. To calculate sample size we have considered confidence interval $95 \%$, power of the study $80 \%$, ratio of cases to controls $=1$, hypothetical proportion exposure of controls 40\%, hypothetical proportion exposure of cases $70 \%$, odds ratio 3.4 and sample size to be 46 each. The cases $(n=50)$ were diagnosed as PCOS based on Rotterdam's criteria and 50 controls of equivalent age group and body mass index without any endocrine disorders and not on any hormonal therapy were selected. Lipid profile including total cholesterol (TC), high-density lipoprotein (HDL), low density lipoprotein (LDL), very low density lipoprotein (VLDL), triglyceride (TG) after 12 hour of overnight fasting were measured and compared for both the groups. Patients on hormonal therapy and those with type 1 and type 2 diabetes mellitus were not included for this study. Similarly patients with other endocrinopathies like thyroid dysfunction and hyperprolactinemia are also excluded from our study. The data was compiled and analysed using graph pad.

\section{RESULTS}

Table 1: Comparison of age among PCOS patients and controls.

\begin{tabular}{|lllll|}
\hline $\begin{array}{l}\text { Age in } \\
\text { total } \\
\text { years }\end{array}$ & \multicolumn{3}{c}{$\begin{array}{c}\text { PCOS cases } \\
(\mathrm{n}=50)\end{array}$} & $\begin{array}{l}\text { Control } \\
(\mathrm{n}=50)\end{array}$ \\
\hline $18-20$ & 12 & 24 & 10 & $\%$ \\
\hline $21-25$ & 18 & 36 & 20 & 40 \\
\hline $26-30$ & 12 & 24 & 10 & 20 \\
\hline $31-35$ & 8 & 16 & 10 & 20 \\
\hline Total & 50 & 100 & 50 & 100 \\
\hline $\begin{array}{l}\text { Mean age } \\
\text { (year) }\end{array}$ & $24.80 \pm 4.76$ & $25.84 \pm 4.50$ \\
\hline P value $=0.2643(\mathrm{NS})$ & & \\
\hline
\end{tabular}

From Table 1 it's clear that both groups are properly matched as far as age is concerned and there is no difference for age in both groups. As shown in Table 2 the BMI is properly matched between cases and controls and statistically there is no significant difference. Table 3 shows that the mean \pm sd of total cholesterol level in the study and control group is $202.12 \pm 40.18 \mathrm{mg} / \mathrm{dl}$ and $171.48 \pm 17.74 \mathrm{mg} / \mathrm{dl}$ respectively and this is statistically highly significant (p-value <0.0001). Similarly the mean \pm sd of triglyceride level in cases and controls is $162.38 \pm 70.40 \mathrm{mg} / \mathrm{dl}$ and $131.46 \pm 27.16 \mathrm{mg} / \mathrm{dl}$ respectively which is also statistically significant (pvalue $=0.0046$ ). In contrast to the above finding though the mean LDL and VLDL level slightly higher in study group, this increase is statistically not significant. Similarly the slight decrease in mean HDL level in study group compared to the control is statistically not significant.

Table 2: Distribution of cases according to BMI.

\begin{tabular}{|lllll|}
\hline & \multicolumn{2}{c|}{ PCOS cases } & \multicolumn{2}{c|}{ Control $(\mathrm{n}=50)$} \\
\hline BMI & $\mathrm{n}$ & $\%$ & $\mathrm{n}$ & $\%$ \\
\hline $\begin{array}{l}\text { Underweight } \\
(\mathrm{BMI}<18)\end{array}$ & 3 & 6 & 2 & 4 \\
\hline $\begin{array}{l}\text { Normal body } \\
\text { Weight } \\
(\text { BMI18-25) }\end{array}$ & 15 & 30 & 18 & 36 \\
\hline $\begin{array}{l}\text { Overweight } \\
\text { (BMI 25-30) }\end{array}$ & 15 & 30 & 15 & 30 \\
\hline $\begin{array}{l}\text { Obese } \\
(\text { BMI>30) }\end{array}$ & 17 & 34 & 15 & 30 \\
\hline Total & 50 & 100 & 50 & 100 \\
\hline $\begin{array}{l}\text { Mean BMI } \\
\text { P value }= \\
0.5298(N S)\end{array}$ & $26.56 \pm 4.42$ & $26.02 \pm 4.14$ \\
\hline
\end{tabular}

Table 3: Lipid profile in PCOS.

\begin{tabular}{|llll|}
\hline $\begin{array}{l}\text { Lipid } \\
\text { parameters }\end{array}$ & $\begin{array}{l}\text { PCOS } \\
(\text { mean } \pm \text { SD) }\end{array}$ & $\begin{array}{l}\text { Control } \\
(\text { mean } \pm \text { SD) }\end{array}$ & P value \\
\hline $\begin{array}{l}\text { Cholesterol } \\
(\mathrm{mg} / \mathrm{dl})\end{array}$ & $202.12 \pm 40.18$ & $171.48 \pm 17.74$ & $<0.0001(\mathrm{~S})$ \\
\hline $\begin{array}{l}\text { Triglycerides } \\
(\mathrm{mg} / \mathrm{dl})\end{array}$ & $\begin{array}{l}162.38 \pm \\
70.40\end{array}$ & $\begin{array}{l}131.46 \pm \\
27.16\end{array}$ & $0.0046(\mathrm{~S})$ \\
\hline LDL $(\mathrm{mg} / \mathrm{dl})$ & $\begin{array}{l}124.44 \pm \\
29.38\end{array}$ & $\begin{array}{l}121.06 \pm \\
20.97\end{array}$ & $0.5094(\mathrm{NS})$ \\
\hline HDL $(\mathrm{mg} / \mathrm{dl})$ & $39.9 \pm 10.11$ & $42.86 \pm 8.67$ & $0.1193(\mathrm{NS})$ \\
\hline $\begin{array}{l}\text { VLDL } \\
(\mathrm{mg} / \mathrm{dl})\end{array}$ & $24.34 \pm 8.578$ & $23.62 \pm 7.55$ & $0.6568(\mathrm{NS})$ \\
\hline
\end{tabular}

Table 4: Comparison of lipid parameters among obese and non-obese PCOS patients.

\begin{tabular}{|lll|}
\hline BMI & $\begin{array}{l}\text { Total } \\
\text { cholesterol(mg/dl) } \\
\text { mean } \pm \text { sd }\end{array}$ & $\begin{array}{l}\text { Triglyceride } \\
\text { (mg/dl) } \\
\text { mean } \pm \text { sd }\end{array}$ \\
\hline $\begin{array}{l}>25(\mathrm{~N}=32) \\
\text { Obese } \\
\text { PCOS }\end{array}$ & $206.90 \pm 37.55$ & $170.65 \pm 70.57$ \\
\hline $\begin{array}{l}<25(\mathrm{~N}=18) \\
\text { non-obese } \\
\text { PCOS }\end{array}$ & $193.61 \pm 44.30$ & $147.66 \pm 69.60$ \\
\hline P- value & $0.2659(\mathrm{NS})$ & $0.2721(\mathrm{NS})$ \\
\hline
\end{tabular}

In Table 4 we have tried to compare total cholesterol level and triglyceride level among obese and non-obese 
PCOS patients. Interestingly we found that the difference is statistically not significant ( $\mathrm{p}$-value $=0.2659$ and 0.2721 for total cholesterol and triglyceride respectively) which further supports the results we have obtained previously that total cholesterol and triglyceride level rises in PCOS patients irrespective of BMI.

\section{DISCUSSION}

This study shows that the proportion of dyslipidemia in our population with PCOS was quite high. In our study $78 \%$ of PCOS patients had at least one abnormal lipid parameter. The most common type of dyslipidemia in our study population was decreased HDL level (76\%) which is also decreased in $68 \%$ cases of controls but the difference was not statistically significant. Next most common finding in our study was increase in total cholesterol (52\%) and triglyceride levels (38\%). 32\% patients had elevated LDL using the cut-off of $130 \mathrm{mg} / \mathrm{dl}$ and $12 \%$ had increase VLDL. Among these only the rise in serum levels of total cholesterol and triglyceride were statistically significant when compared to healthy adults.

The level of triglyceride can be a contributory factor for adiposity in PCOS women. ${ }^{8}$ A higher mean TC/HDL cholesterol and LDL cholesterol/HDL cholesterol were observed in PCOS compared to controls in the study by Xiang SK et al. ${ }^{9}$ Gateva A et al showed that even after weight adjustment, the lipid abnormalities persisted. ${ }^{10}$ The results of the study by Cristian-Ioan IUHAS et al showed that women with PCOS have altered lipid profile, with higher cholesterol levels (both total and LDL) and lower HDL cholesterol compared with healthy women. ${ }^{11}$ The study by Amini L et al does not support the notion that PCOS affects serum lipid levels except in the term of TG in PCOS women with BMI $>25 .^{12}$ The present study confirms the presence of a more atherogenic lipid profile in women with PCOS. Taponen et al found that triglyceride accumulation leads to disease risk factors. ${ }^{13}$

It is well known that obesity influences lipid profile independently of the presence or absence of PCOS. We tried to compare lipid profile among PCOS patients and healthy controls excluding age and obesity as confounding factors. Also we have compared the serum levels of triglyceride and total cholesterol among lean PCOS and obese PCOS group in our study to confirm the findings. According to our study there are specific abnormal lipid parameters that got deranged independent of obesity i.e. total cholesterol and triglyceride and obesity may play a role in derangement of other lipid parameters such as decrease in HDL, increase in LDL. Another study by Valkenburg $\mathrm{O}$ et al showed higher serum levels of TG, TC, LDL-C, and Apo B in combination with lower levels of HDL-C and Apo A-I in obese PCOS cases when compared with obese controls. ${ }^{14}$

The only limitation of this study is less number of cases and controls. Also we agree with the fact that the results of such type of study would be better reflected in a nested cohort study than a case control study. So this study must be repeated in more number of lean PCOS cases and in a better study design to extract further evidences.

\section{CONCLUSION}

Though there are various study reports in the support and also against the recommendation of lipid profile in PCOS patients the fact that PCOS patients are more prone for atherogenic lipid profile and hence cardiovascular diseases is an established one. We found that the atherogenic lipid profile found in PCOS patients is independent of their age and body mass index. So we recommend that both lean as well as obese PCOS patients should be screened for lipid profile to prevent future cardiac complications.

\section{Funding: No funding sources}

Conflict of interest: None declared

Ethical approval: The study was approved by the Institutional Ethics Committee

\section{REFERENCES}

1. Amsterdam ESHRE/ASRM-Sponsored 3rd PCOS Consensus Workshop Group. Consensus on women's health aspects of polycystic ovary syndrome (PCOS) Hum Reprod. 2012;27:14-24.

2. Adams J, Franks S, Polson DW, Mason HD, Abdulwahid N, Tucker M, et al. Multi follicular ovaries: clinical and endocrinefeatures and response to pulsatile gonadotropin releasing hormone. Lancet. 1985;2:1375-9.

3. Azziz R, Carmina E, Dewailly D, DiamantiKandarakis E, Escobar-Morreale HF, Futterweit W, et al. Criteria for defining polycystic ovary syndrome as a predominantly hyperandrogenic syndrome: an Androgen Exess Society guideline. J Clin Endocrinol Metab. 2006;91:4237-45.

4. Dunaif A, Segal K, Futterweit W, Dobrjanky A. Profound peripheral resistance independent of obesity in polycystic ovary syndrome. Diabetes. 1989;38:1165-74.

5. Diamanti-Kandarakis E. Insulin resistance in PCOS. Endocr. 2006;30:13-7.

6. Chang RJ. A practical approach to the diagnosis of polycysticovary syndrome. Am J Obstet Gynecol. 2004;191:713-7.

7. Richardson MR. Current perspectives in polycystic ovary syndrome. Am Fam Physician. 2003;68:697704.

8. Lambrinoudak I, Christodoulakas G, Rizos D, Eunomou E, Afgeitis J, Vlachou S. Endogenous sex hormones and risk factors for atherosclerosis in health Greek post-menopausal women. Eur J. Endocrinol. 2006:154(6);907-16.

9. Xiang SK, Hua F, Tang Y, Jiang XH, Zhuang Q, Qjan FJ. Relationship between serum lipoprotein ratios and insulin resistance in polycystic ovary syndrome. Int J Endocrinol 2012;2012:173281. 
10. Gateva A, Kamenov Z. Cardiovascular Risk Factors in Bulgarian Patients with Polycystic Ovary Syndrome and/or Obesity. Obstet Gynecol Int 2012;ArticleID:306347.

11. Cristian-Ioan I, Nicolae C, Dan M. Lipid Parameters in Patients with Polycystic Ovary Syndrome, Applied Medical Informatics. 2012;31(4):27-32.

12. Leila A, Mohammad RS, Fatemeh O, Koorosh K, Haleh M. Lipid Profile in Women with Polycystic Ovary Syndrome; Crescent Journal of Medical and Biological Sciences. 2014:1(4):147-50.
13. Taponen S, Martikainen H, Jarvelin MR, Sovio U, Laitinen,A, Pouta A, et al . Metabolic cardiovascular disease risk factors in women with self reported symptoms of Oligomenorrhea and Hirsuitism. J. Clin. Endocrinol. Metab. 2004;89(5):2114-8.

14. Valkenburg O, Steegers-Theunissen RP, Smedts HP, Dallinga-Thie GM, Fauser BC, Westerveld EH, et al. A more atherogenic serum lipoprotein profile is present in women with polycystic ovary syndrome: a case-control study. J Clin Endocrinol Metab. 2007;93:470-6.

Cite this article as: Panda SR, Rout PK, Chandra C. A case control study of role of lipid profile in polycystic ovarian syndrome: is there any role in non-obese polycystic ovary syndrome? Int J Reprod Contracept Obstet Gynecol 2016;5:1981-4. 